Case 3116

\title{
Gnomulus Thorell, 1890 (Arachnida, Opiliones): proposed designation of $G$. sumatranus Thorell, 1891 as the type species
}

Peter J. Schwendinger

Muséum d'Histoire Naturelle, Departement des Arthropodes et d'Entomologie I, Case postale 6434, CH-1211 Genève 6, Switzerland (e-mail: peter.schwendinger@mhn.ville-ge.ch)

Jochen Martens

Institut für Zoologie, Johannes Gutenberg-Universität Mainz, Saarstrasse 21, D-55099 Mainz, Germany (e-mail: martens@mail.uni-mainz.de)

Abstract. The purpose of this application is to conserve the usage of the generic name Gnomulus Thorell, 1890 for an opilionid (family ONCOPODIDAE) by the designation of G. sumatranus Thorell, 1891 as the type species. This designation was the author's clear intention and is in accord with the subsequent understanding and usage of the genus. However, Gnomulus was described with G. rostratus Thorell, 1890 as the type species by monotypy. Gnomulus sumatranus and $G$. rostratus are morphologically distinct and it is possible that they will require generic separation in the future. Members of the genus Gnomulus are known from the Himalayan Region and from southeast Asia.

Keywords. Nomenclature; taxonomy; Arachnida; Opiliones; ONCOPODIDAE; Gnomulus; Gnomulus sumatranus; Gnomulus rostratus.

1. In 1890 Thorell (p. 378) described the genus Gnomulus and designated 'Gnomulus sumatranus' as the type species. However, he did not then describe this species and the name sumatranus was not made available until a year later. Thorell (1890) referred to 'G. sumatranus' as 'Typus: G. sumatranus, Thorell' and in a footnote recorded 'species in opere nondum edito (Opilioni nuovi ... ) a me descripta' (species to be described by me in a not yet edited paper). Thorell described and illustrated G. sumatranus from Sumatra in 1891 (pp. 759-763, figs. 37-40).

2. Thorell $(1890$, p. 378$)$ described another species, Gnomulus rostratus, at the same time as the genus Gnomulus and, as the single included species with an available name, this is the type species by monotypy.

3. Clearly Thorell's intention was to fix Gnomulus sumatranus as the type species of Gnomulus and this formally invalid designation has been accepted and never questioned by subsequent authors. There are considerable advantages in maintaining G. sumatranus as the type of the genus.

4. Gnomulus sumatranus is a well known species. The external morphology of the male from the type series was illustrated in the original description (Thorell, 1891, pp. 759-763, pl. 9, figs. 37-40) and later also by Roewer (1923, pp. 61-62, figs. 64a-c); another male and its genitalia were illustrated by Loman (1903, figs. O, V-f, pl. 11, 
figs. 19, 21). On the other hand, Gnomulus rostratus was described in a lengthy Latin text without illustrations (Thorell, 1890, pp. 378-381) and has remained a virtually unknown species. Although fairly conspicuous and fairly common at the type locality (Penang Island, Malaysia) and nearby localities on the mainland, there has never been a subsequent record of this species in the literature. Further specimens of $G$. rostratus, which were found later, were misidentified in Roewer's collection. Pelitnus insularis Roewer, 1927, a species now included in Gnomulus and most closely related to $G$. rostratus, was not recognized as such. The penis morphology of G. rostratus has not hitherto been studied and published.

5. Gnomulus sumatranus Thorell, 1891 was based on a type series of material of both sexes (one male, three females and two juveniles), preserved in the Museo Civico di Storia Naturale, Genoa. Gnomulus rostratus Thorell, 1890 was based on a single female holotype, also preserved in the Genoa collections. We propose (Schwendinger \& Martens, in press) to designate the male specimen as the lectotype of G. sumatranus. All relevant illustrations (apart from the figure of a leg tarsus of a juvenile) in the original description of the species refer to this specimen (Thorell, 1891, pl. 9, figs. 37-39). It is in perfect condition, with its genitalia intact, and provides the most informative and reliable characters for identification. Female genitalia are uninformative at the species level.

6. The nominal species Gnomulus sumatranus and G. rostratus are dissimilar in a number of characters. Features of the genitalia of $G$. sumatranus accord well with other species (except G. rostratus and Pelitnus insularis) described under Gnomulus and Pelitnus (now in synonymy with Gnomulus). However, G. rostratus and $G$. insularis, and a further three closely related species which we will describe from Thailand and Malaysia (Schwendinger \& Martens, in preparation), are markedly different in external and genital morphology. These may need to be generically separated as more such species become known. The name Pelitnus Thorell, 1891 (p. 757, based on P. armillatus Thorell, 1891, which has a juvenile type specimen) is available for $G$. sumatranus and its allied species but we (Martens \& Schwendinger, 1998 , p. 526) have recently placed Pelitnus in the synonymy of Gnomulus and transferred all 17 known species to the latter genus. Transferring these, and the other species (except G. rostratus and G. insularis) currently in Gnomulus, back into Pelitnus and reinstating the latter name, would cause unnecessary confusion and instability. In our view it would be preferable not to change the long accepted understanding of Gnomulus but, instead, to establish a new genus for $G$. rostratus and related species if this is required in the future.

7. We propose that Gnomulus sumatranus Thorell, 1891 be maintained as the type species of Gnomulus Thorell, 1890 in accord with the understanding of the genus since its original publication in 1890. Usage of the generic name is demonstrated in the recent publications by Sørensen (1932, p. 210), Martens (1977, p. 298), Tsurusaki (1990, pp. 59-62), Schwendinger (1992, pp. 177, 197, 198) and Martens \& Schwendinger (1998).

8. The International Commission on Zoological Nomenclature is accordingly asked:

(1) to use its plenary powers to set aside all previous fixations of type species for the nominal genus Gnomulus Thorell, 1890 and to designate Gnomulus sumatranus Thorell, 1981 as the type species; 
(2) to place on the Official List of Generic Names in Zoology the name Gnomulus Thorell, 1890 (gender: masculine), type species by designation under the plenary powers in (1) above Gnomulus sumatranus Thorell, 1891;

(3) to place on the Official List of Specific Names in Zoology the name sumatranus Thorell, 1891, as published in the binomen Gnomulus sumatranus (specific name of the type species of Gnomulus Thorell, 1890).

\section{References}

Loman, J.C.C. 1903. Vergleichend anatomische Untersuchungen an chilenischen und anderen Opilioniden. Zoologische Jahrbücher, (Supplement 6) 3: 117-200.

Martens, J. 1977. Opiliones aus dem Nepal-Himalaya. III. Oncopodidae, Phalangodidae, Assamiidae (Arachnida). Senckenbergiana Biologica, 57: 295-340.

Martens, J. \& Schwendinger, P.J. 1998. A taxonomic revision of the family Oncopodidae 1. New genera and new species of Gnomulus Thorell (Opiliones, Laniatores). Revue Suisse de Zoologie, 105(3): 499-555.

Roewer, C.F. 1923. Die Weberknechte der Erde. Systematische Bearbeitung der bisher bekannten Opiliones. iv, 1116 pp. Fischer, Jena.

Schwendinger, P.J. 1992. New Oncopodidae (Opiliones, Laniatores) from Southeast Asia. Revue Suisse de Zoologie, 99(1): 177-199.

Schwendinger, P.J. \& Martens, J. In preparation. A taxonomic revision of the family Oncopodidae 2. The genus Gnomulus Thorell (Opiliones, Laniatores). Revue Suisse de Zoologie.

Sørensen, W. 1932. Descriptiones laniatorum (Arachnidorum Opilionum Subordinis) fecit William Sørensen opus posthumum recognovit et edidit Kai L. Hendriksen. Mémoires de l'Académie Royale des Sciences et des Lettres de Danemark, Copenhague (Section des Sciences), (9)3(4): 199-422.

Thorell, T. 1890. Aracnidi di Pinang raccolti nel 1889 dai signori L. Loria e L. Fea. Annali del Museo Civico di Storia Naturale di Genova, (2)10: 269-383.

Thorell, T. 1891. Opilioni nuovi o poco conosciuti dell'Arcipelago Malese. Annali del Museo Civico di Storia Naturale di Genova, (2)10: 669-770.

Tsurusaki, N. 1990. Gnomulus minor, a new species of oncopodid harvestmen from Luzon, the Philippines. Acta Arachnologica, 39: 59-62.

Comments on this case are invited for publication (subject to editing) in the Bulletin; they should be sent to the Executive Secretary, I.C.Z.N., c/o The Natural History Museum, Cromwell Road, London SW7 5BD, U.K. (e-mail: iczn@nhm.ac.uk). 


\section{$2 \mathrm{BHL}$ Biodiversity Heritage Library}

Schwendinger, P J and Martens, J. 1999. "Case 3116 Gnomulus Thorell, 1890 (Arachnida, Opiliones): proposed designation of G. sumatranus Thorell, 1891 as the type species." The Bulletin of zoological nomenclature 56, 171-173. https://doi.org/10.5962/bhl.part.23061.

View This Item Online: https://www.biodiversitylibrary.org/item/45032

DOI: https://doi.org/10.5962/bhl.part.23061

Permalink: https://www.biodiversitylibrary.org/partpdf/23061

\section{Holding Institution}

Natural History Museum Library, London

\section{Sponsored by}

Natural History Museum Library, London

\section{Copyright \& Reuse}

Copyright Status: In copyright. Digitized with the permission of the rights holder.

License: http://creativecommons.org/licenses/by-nc-sa/3.0/

Rights: https://biodiversitylibrary.org/permissions

This document was created from content at the Biodiversity Heritage Library, the world's largest open access digital library for biodiversity literature and archives. Visit BHL at https://www.biodiversitylibrary.org. 